\title{
MERCEDES BENZ INCISION: A MODIFICATION OF THE MAGPI PROCEDURE FOR DISTAL HYPOSPADIAS REPAIR
}

\author{
By \\ Mohamed Shahin and Mohamed Ramadan Rehan* \\ Department of surgery (Pediatric Surgery Unit) and Department of Urology* \\ Faculty of Medicine - Al-Azhar University
}

\begin{abstract}
Background: Hypospadias is one of the most common congenital abnormalities of the male genito-urinary system. The main goal in surgery is to attain cosmetic and functional correction. Hypospadias repair should be done with minimal complications. Duckett innovated meatal advancement and glanuloplasty (MAGPI) procedure and was applied for correction of this lesion.
\end{abstract}

Objectives: Evaluation of Mercedes Benz incision as a modification of the MAGPI procedure for repair of distal hypospadias with mobile meatus.

Paitents and Methods: Forty five children with distal hypospadias and mobile meatus were operated on using this technique. Mean age of patients was $2 \pm 4.2$ year (1-10) years.

Results: Patients were discharged home after 3 days. The operation resulted in a slit-like urethral meatus. Follow-up was done for 6 months. Good cosmetic and functional results were obtained in 44 patients $(97.78 \%)$. One patient $(2.22 \%)$ had mild meatal stenosis that corrected by frequent dilation. Complication occurred in one patient $(2.22 \%)$ who suffered from dehiscence of the wound and retraction of the meatus. The meatal retraction was corrected using circum-meatal urethral advancement technique.

Conclusion: Mercedes Benz incision as a modification of the MAGPI procedure was feasible and suitable for appropriately selected cases with distal hypospadias and mobile meatus. It provides a cosmetically natural vertical slit-like urethral meatus at the tip of the glans.

Key words: distal hypospadias, MAGPI procedure, Mercedes Benz incision, congenital abnormalities.

\section{INTRODUCTION}

Hypospadias is one of the most common congenital abnormalities of the male genito-urinary system; with prevalence of $0.3 \%$ in male newborns (Snodgrass, 2012). There are multiple classifications for hypospadias according to the location of the external meatus. About $65 \%$ of cases are classified as distal hypospadias (Shukla et al., 2016).
The main goal in surgery on this anomaly is to attain cosmetic and functional correction. Hypospadias repair should be done with minimal complications. More than 300 surgical procedures for hypospadias repair have been described (Gupta et al., 2017). The choice of surgical procedure is often based on the surgeon's experience and morphology of the penis. 
Duckett innovated meatal advancement and glanuloplasty (MAGPI) procedure for the correction of this lesion; although usually successful, the incidence of meatal retraction has been recognized after MAGPI. The $\mathrm{M}$ inverted $\mathrm{V}$ glansplasty was designed to correct meatal retraction and the abnormal glanular shape sometimes occurred after the MAGPI (Djakovic et al., 2008).

The aim of the study was to evaluate Mercedes Benz incision as a modification of the MAGPI procedure in the management of different types of distal hypospadias and analyze the results.

\section{PATIENTS AND METHODS}

This prospective study was done from July 2015 to July 2017. This modification was used in the management of distal hypospadias in 45 children whose agesranged from one to ten(mean $2 \pm 4.2$ ) years. Children had differentvarieties of distal hypospadias including thirty cases $(66.6 \%)$ with glanular hypospadias and coronal was in fifteen $(33.3 \%)$ children. All cases were fresh except six $(13.3 \%)$ children were recurrent cases, whom had undergone other surgical procedures for distal hypospadias and failed. The cases were repaired by a single surgeon.

Abdomino-pelvic ultra-sonography was done in all cases to rule out other urogenital anomalies. The mean follow up period for above cases was six months postoperatively.

Inclusion criteria: Glanular and coronal hypospadias, dorsal tissue present on the glans, mobile urethral meatus and shallow glanular groove (Fig. 1).

Exclusion criteria: Cases with proximal penile, mid penile and subcoronal variety of hypospadias, hypospadias with chordee, congenital hypoplastic urethra and deep glanular groove.

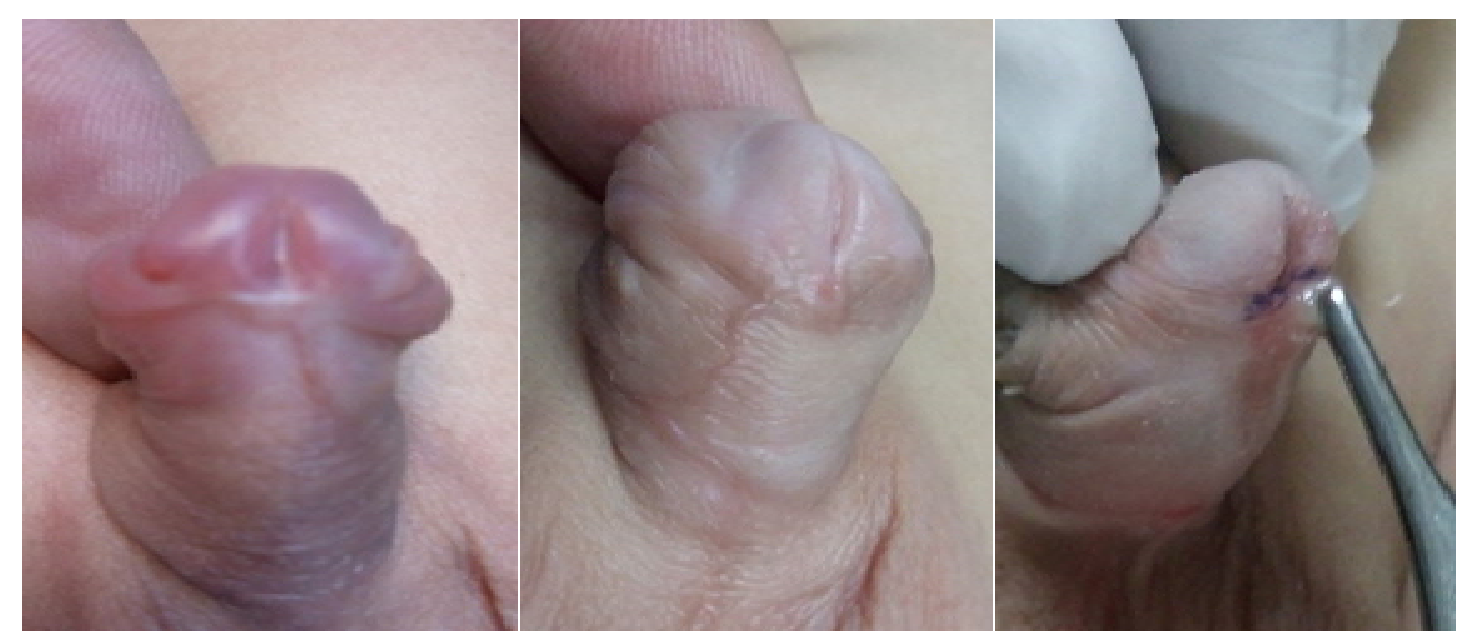

Figure (1): Different cases of distal hypospadias with mobile urethral meatus

Procedure: All patients received routinely caudal block combined to general anesthesia tominimize the postoperative pain. A traction suture of vicryl 3/0 was placed through the glans dorsal to the glanular tip. An 8-10 F size catheter was passed into the bladder. Proper assessment of the glans and meatus 
was mandatory after anesthesia and after confirming that the meatus was mobile and can be pushed to the tip of the glans using a fine toothed forceps. Epinephrine 1: 200,000 dilution was applied locally to minimize intra-operative bleeding. A rubber tourniquet was placed at the root of the penis after complete degloving of the penis. An artificial erection test was done for all doubtful cases to assess the presence and degree of chordee.
Mercedes benz incision was outlined on the glans. The center of Mercedes benz was just above the ridge distal to the meatus. The longitudinal limb extended to the glanular tip where the neo-meatus was located. The incision was deepened, and the glanular flaps were mobilized to allow more mobility of the meatus (Fig. 2).
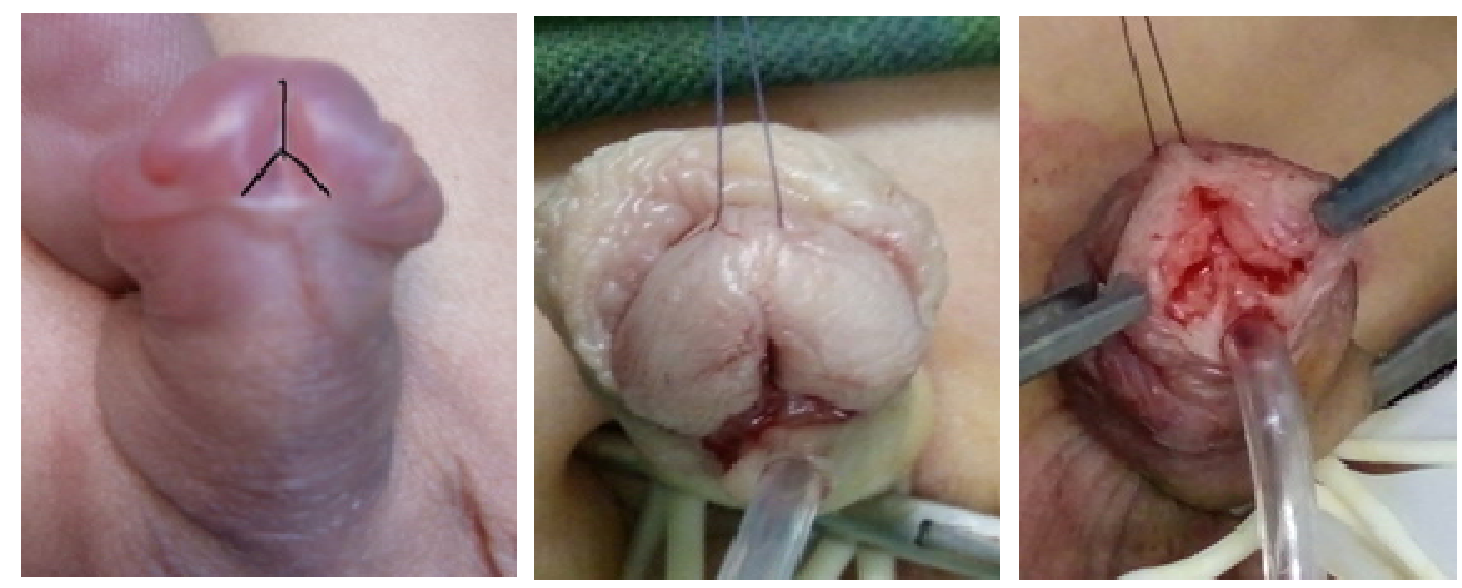

Figure (2): Mercedes benz incision was outlined on the glans and deepened with good mobilization o fglanular flaps.

When the meatus was narrow or pin hole, it was incised to be wide enough to accommodate a nelaton catheter $8 \mathrm{~F}$ or larger according to the patient age and size of the penis. The use of sharp scissors and traction was beneficial to avoid injury of the distal urethra. Traction suture was applied on the glanular wings, and the 2 oblique limbs of the Mercedes benz incision were deepened using sharp scissors starting distally down to the coronal sulcus. The ventral edge of the urethra was advanced easily up to the top of the glans. The glanular wings were wraped around the urethra without any tension (Fig. 3). 

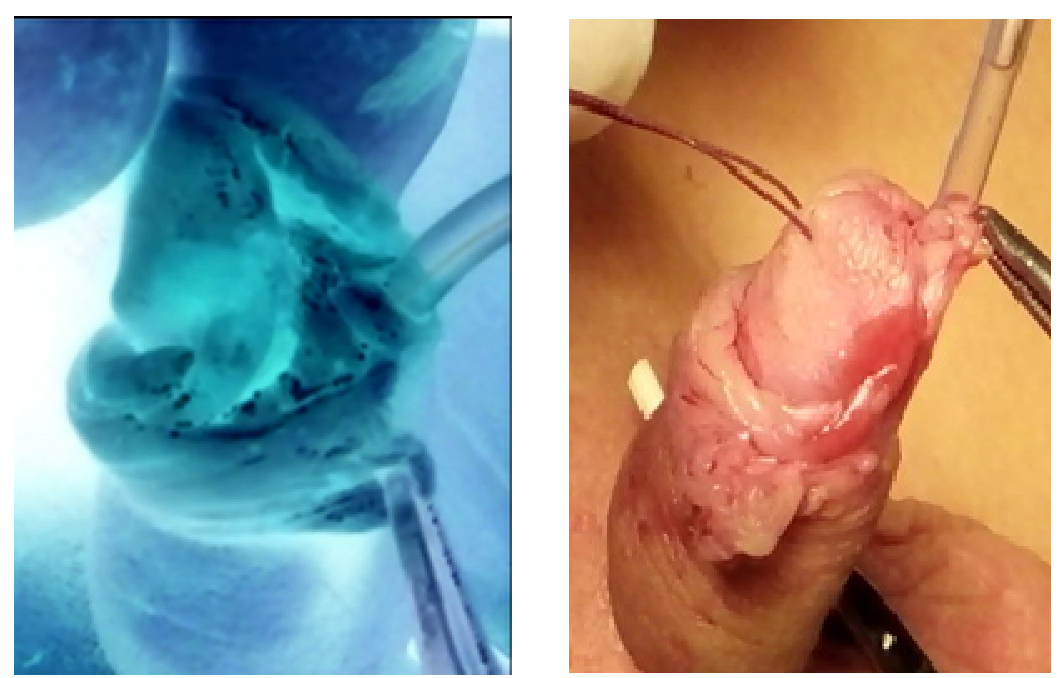

Figure (3): The 2 oblique limbs of the incision was deepened distally down to the coronal sulcus and the urethral meatus was advanced easily

Mid-line suture was taken to fix the tip of the neo-meatus to the glans. The upper margins of the two glanular wings were sutured to the edges of the urethral meatus using 3 sutures of Vicryl 6/0 on each side.
The medial margins of the glanular wings were sutured with each other in the midline using Vicryl $6 / 0$ in a transverse mattress manner (Fig. 4).
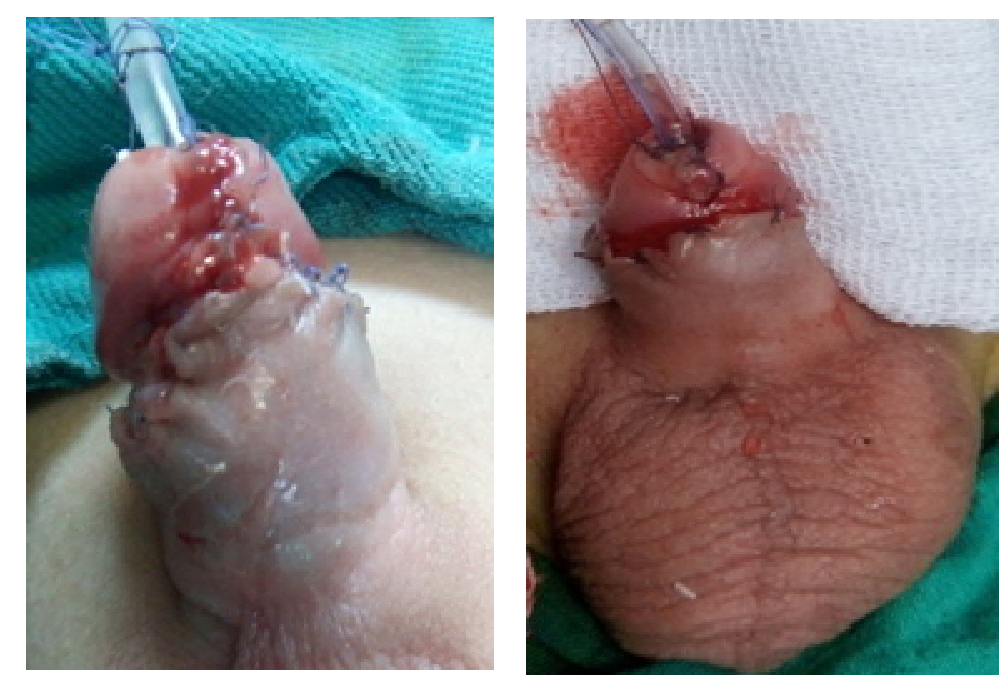

Figure (4): Glano-plasty was done using Vicryl 6/0 in a transverse mattress manner

Local fucidic acid ointment with normal gauze was applied to the wound, and adhesive tape fixed the sterile dressing to the penis with the catheter against suprapubic area. The urethral catheter was left for (2-4) days depending on the degree of meatal mobilization, level and type of hypospadias (fresh or recurrent) and post- operative penile edema. The child was discharged 12 hours after catheter removal.

Statistical analysis: Data were summarized by mean \pm standard deviation and categorical variables were expressed as percentage $(\%)$. 


\section{RESULTS}

A total of 45 patients with different types of distal hypospadias were subjected to Mercedes Benz incision for repair. Thirty cases had glanular hypospadias, while fifteen cases had coronal hypospadias. The mean age of patients was $2 \pm 4.2$ year $(1-10)$ years. The mean operative time was $35 \pm 17$ (range 27-52) minutes. Dressing of five patients $(11.1 \%)$ was soaked with blood that stopped spontan eously within 24 hours. The

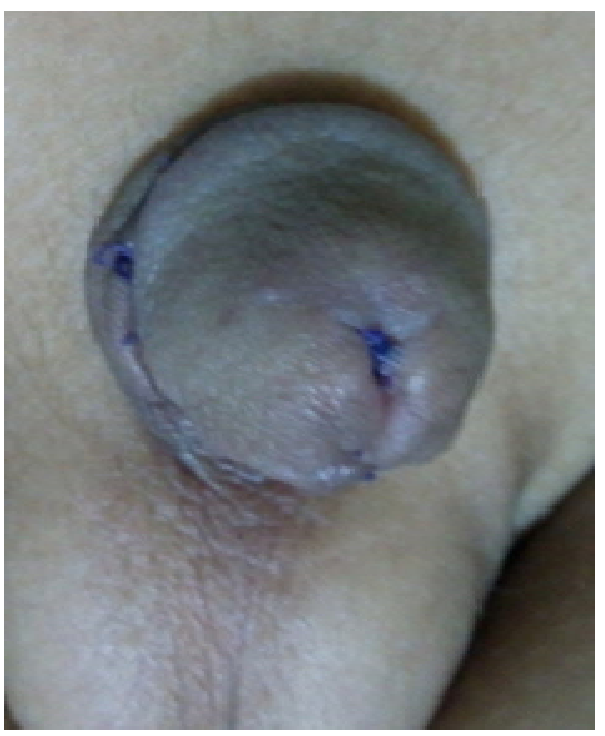

Fig (5): Early posto-perative direct and excellent urinary stream with straight penis \& good slit-like urethral meatus

The mean follow-up period was 6 months. At the follow-up visits, a good slit-like urethral opening in a near normal looking glans was seen in 44 patients (97.78\%) (Fig.5). One patient $(2.22 \%)$ had mild meatal stenosis that corrected by frequent dilatation. Complication occurred mean post-operative hospital stay was $3 \pm$ 1.8 (range 2-7) days depending on the age of the patient and penile edema. All patients were recorded photographically before and after surgery for follow-up and aesthetic evaluation.

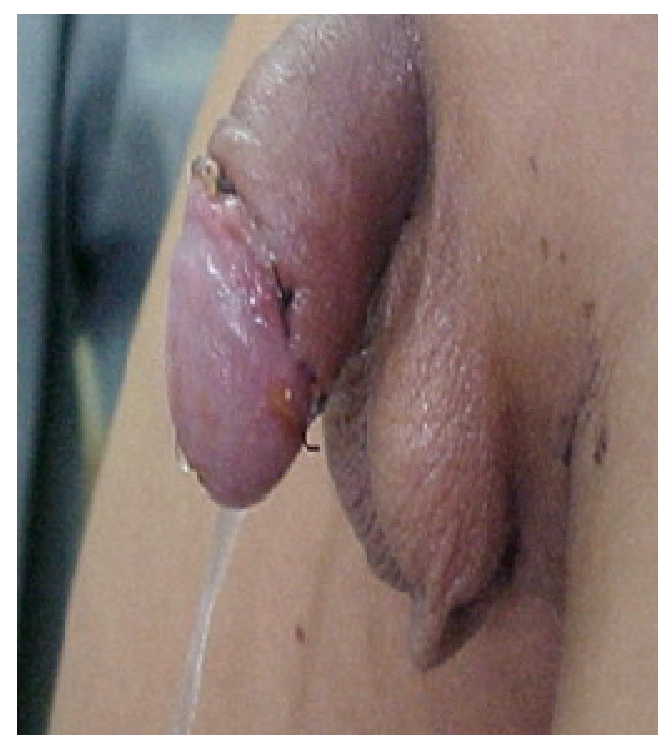

\section{Table (1): Complications of MAGPI procedure with the incision}

\begin{tabular}{|l|c|}
\hline \multicolumn{1}{|c|}{ Complications } & No. of patients. \\
\hline Glanular dehiscence \& Meatal regression & $1(2.22 \%)$ \\
\hline Meatal stenosis & $0(0 \%)$ \\
\hline Urethral fistula & $0(0 \%)$ \\
\hline Cosmetic disfigurement & $0(0 \%)$ \\
\hline
\end{tabular}




\section{DISCUSSION}

Choice of procedure for each case depends on site and size of the meatus, presence of penile curvature, condition of the ventral parameatal skin and the urethral plate, depth of the glandular groove, etc. So, no single technique is ideal for all types of distal hypospadias. Meatal advancement procedure has been widely experienced for distal hypospadias repair but this technique is not ideal for children with thin or tough ventral parameatal skin or with mega-meatus (Dutta, 2014).

For the past 30 years, surgical procedures had an unacceptable morbidity in distal hypospadias and did not accurately achieve shift of the urethral meatus to the tip of the glans. Because those patients showed a minimal functional impairment, surgeons were opposed to undertake an operation because the surgical morbidity might leave the patient worse off than if the hypospadias were left untreated. During the last years, several procedures became available for the surgical correction of glanular hypospadias.

The MAGPI was introduced by Duckett in 1981 (Djakovic et al. (2008). The technique had not always complete satisfaction, which led the author to modify and polish it in 1991 to reduce the risk of meatal retraction (Stein, 2012). However, Chertin et al. (2010) concluded that Heineke-Mikulicz. (2007) used MAGPI with tissue re-arrangement. These cases had an abnormal meatal and glanular configuration, that even in the glanular tip but may appear round and abnormally puckered .
Hadidi. (2010) introduced the double Y glanuloplasty technique which is suitable for selected cases with glanular hypospadias and mobile meatus. It achieves a cosmetically natural vertical slit at the tip of the glans.

Elemen and Tugay. (2012) stated that Harrison and Grobbelaar. (1997) modified MAGPI by having a V-shaped incision around the urethral meatus before its mobilization and making deep glanular wings. The meatus is advanced to the glanular tip and two deep glanular wings can approximate and wrapped around the urethra. This procedure is based on the amenability of the urethra to mobilization and advancement to the glans tip .

Keays and Dave. (2017) described a procedure for "minimal distal balanitic hypospadias." This technique includes excision of the small triangle distal to the urethral meatus and suturing the distal meatus to the tip of the glans as a first step of MAGPI technique.

Adorisio et al. (2010) described a modification of Koff procedure where a " $\Psi$ " incision on the distal part of the glans and then a deep incision of the distal urethral plate were introduced to put the urethra inside the glans.

In the present study, Mercedes benz incision was performed distal to the meatus. The vertical limb reaches to the tip the glans where the meatal tip located. The two oblique incisions were deepened, and the two lateral glanular flaps are mobilized to get more mobility of the meatus. 
The choice of age of hypospadias repair was determined by the time of referral and ranged from1 to 10 years. Early surgical interference is beneficial in patients with straining during micturition. The younger children have quicker recovery and less complication than the older children (Elkassaby et al., 2013).

The highest ages of hypospadias repair caused much post-operative hardness in controlling the child's activity; and his emotional troubles caused by dressing and stent removal. Elkassaby et al. (2013) stated that these results agree with Belman, (1988) performed surgery upon children at ages of 2 months and 11 months and noticed lowering of technical complications and diminish of the anxiety. Also they found no variance in complication rates regardless the age.

In general, many reports suggested that the proper age for genital surgery is between 6 to 12 months of age. This period seems to insulate most infants from the psychologic, physiologic, and anesthetic trauma associated with hypospadias surgery. Healing seems to occur more quickly and with less scars, young infants resist the stress of surgery more easily (Jorge et al., 2016).

The mean hospital stay period was 2.3 (1-4) days; $94 \%$ of the cases were discharged on the first day after changing the dressing (Guarino etal., 2009).

In this study the urethral catheter is left for (2-4) days depending on the degree of meatal mobilization, level and type of hypospadias (fresh or recurrent) and postoperative penile edema. The child was discharged 12 hours after catheter removal.
The incidence of complications of MAGPI repair seeking a second surgery ranges from $1.2 \%$ to $10 \%$ (Chung et al., 2012). Poor patient selection, as a meatus located too far proximally and the existence of severe chordee, can lead to complications like meatal regression and stenosis (Shukla et al., 2016). To avoid these problems, many authors have reported modifications to this technique (Djakovic et al., 2008).

Kocaman et al. (2017) suggested excision of a deep and tag-shaped glandular tissue piece at meato-plasty, they published the incidence of complications of MAGPI repair requiring a second operation is $3 \%$ in comparison with TIPU which is $9 \%$.

In the present study, one patient had mild meatal stenosis that was corrected by frequent dilation. Complication occurred in one patient $(2.22 \%)$ who suffered from dehiscence of the wound and retraction of the meatus mostly due to infection. The meatal retraction was corrected 6 months later using circum-meatal urethral advancement technique.

All previous studies of MAGPI modifications were performed on fresh cases only. However in this study, the Mercedes benz incision as a modification of MAGPI is useful in selected cases of recurrent distal hypospadias.

Any effort to force a fixed urethral meatus distally is susceptible to complications and regression of the meatus. Sufficient mobilization of the glanular wings permits the surgeon to have a wide, slit-like urethral meatus at the glanular tip of the penis that is unlikely to develop stenosis. 


\section{CONCLUSION}

Mercedes Benz incision as a modification of the MAGPI procedure was feasible and suitable for appropriately selected cases with distal hypospadias and mobile meatus. It provided a cosmetically natural vertical slit-like urethral meatus at the tip of the glans. It also minimized the incidence of meatal retraction with excellent glanular conical shape.

\section{REFERENCES}

1. Adorisio $O$, Elia A, Landi $L$ and Taverna $M$ (2010): The importance of patient selection in the treatment of distal hypospadias using modified Koff procedure. J Pediatr Urol., 6(2): 139-142.

2. Belman (1988) In Elkassaby M., Shahin MM, El-Sayaad IM and Arnos AA (2013).

3. Chertin B, Prat D and Shenfeld O Z (2010): Outcomes of pediatric hypospadias repair in adulthood. Open Access J Urol. 2:57-62.

4. Chung J W, Choi S H, Kim B S and Chung S K (2012): Risk factors for the development of urethra-cutaneous fistula after hypospadias repair: A retrospective study. 53(10):711-5.

5. Djakovic N, Nyarangi-Dix J, Ozturk $A$ and Hohenfellner M. (2008): Hypospadias. Advances in urology. Volume 2008, Article ID 650135, 7 pages.

6. Dutta HK (2014): Distal hypospadias repair: Experience with corpus spongiosum advancement. Journal of Progress in Paediatric Urology, 17(2): 89-92.

7. Elemen L,Tugay M (2012): Limited urethral mobilization technique in distal hypospadias repair with satisfactory results. Balkan MED J. 29:21-5.

8. Elkassaby M., Shahin MM, El-Sayaad IM and Arnos AA (2013): Comparative study between modified Koyanagi and Snodgrass techniques in management of proximal types of hypospadias. Journal of Taibah University Medical Sciences, 8(2): 97-104.
9. Guarino N, Vallasciani SA and Marrocco G (2009): A new suture material for hypospadias surgery: a comparative study. J Urol. 181(3):1318-22.

10. Gupta A, Gupta R and Gupta A (2017); Coparison of interrupted and contiuous suture urethroplasty in TIP hypospadias repair: A prospective study. Arab J Urol., 15(4):312-8.

11. Hadidi AT (2010): Double Y glanuloplasty for glanular hypospadias. Journal of Pediatric Surgery, 45: 655-660.

12. Harrison and Grobbelaar (1997): In Elemen L,Tugay M 2012.

13. Heineke-Mikulicz (2007): In Chertin B, Prat D and Shenfeld O Z (2010).

14. Jorge $J$ C, Raymond $M$ and Brayfield $P$ (2016): Age of the mother as a risk factor and timing of hypospadias repair according to severity. SOJ Urol Nephrolopen access. 2(1):766-87.

15. Keays $M$ A and Dave S (2017): Current hypospadias management: Diagnosis, surgical management and long term patient-centred outcomes. Can Urol Assoc J. 11:48-53.

16. Kocaman OH, Gunendi T, Anadolulu AI, Dorterler ME, and Boleken ME (2017): Coronal hypospadias: Meatal advancement and glanuloplasty or tubularized incised plate urethroplasty? J Surg Open Access, 3(5): 1-4

17. ShuklaA K, SinghA $P$, SharmaP and ShuklaJ (2016): MAGPI technique for distal penile hypospadias; modifications to improve outcome at a single center. Arch Int Surg 6(4): 201-5.

18. Snodgrass WT (2012): Hypospadias. Campbell-Walsh Urology. 10th ed. Philadelphia: WB Saunders, pp 3503-36.

19. Stein $R$ (2012): Hypospadias. Eurobean Urology Supplements, 11: 33-45.

20. Vallasciani S, Spagnoli A, Borsellino A,Martini L and Ferro F (2007): Simplifying the surgical approach to glanular and coronal hypospadias: longitudinal urethra lincision and glanuloplasty. J Pediatr Urol., 3:453-6. 


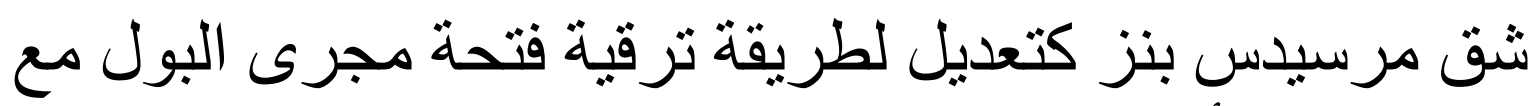 تجميل رأس العضو الذكرى فى تصليح الإحليل السفلى

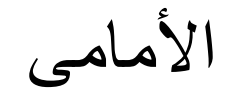 محمد شاهين- محمد رمضان ريحان*}

قسم الجراحة (وحدة جراحة الأطفال) وقسم جراحة المسالك البولية**

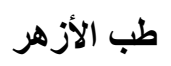

خلفية البحث : الإحليل السفلي هو أحد التشوهات الخلقية شيو عا فى الجهاز البولى التناسلى الذكرى.

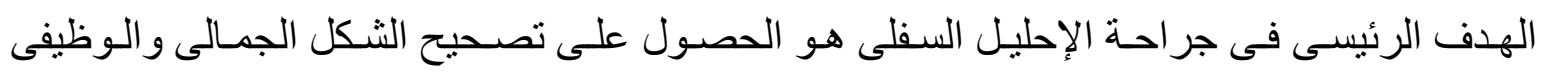
للعضو الذكرى، مع الحد الأدنى من المضاعفات.

الهلف من البحث: تقييم شق مرسيدس بنز كتعديل لطريقة ترقية فتحة مجرى البول مع تجميل رأس

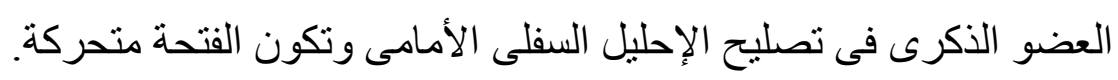

المرضي وطرق البحث: تم إجر اء البحث على خمسـة وأربعين طفلا لديهم إحليل سفلى أمامى وتم

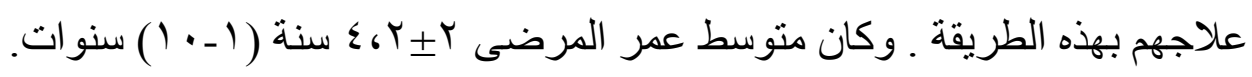

النتائج: عاد المرضى لمناز لهم بعد ب أيام من الجراحة. وتمت المتابعة لمدة 7 أشهر ـوقد كانت النتائج

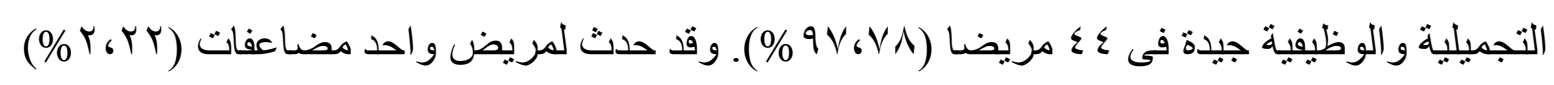

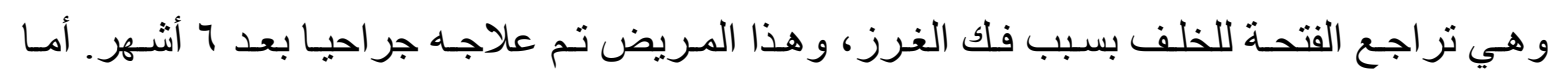
المريض الذى كان يعانى من ضيق بالفتحة فقد نم توسيعها دون تدخل جر احى.

الاستنتاج: شق مرسيدس بنز كتعديل لطريقة ترقية فتحة مجرى البول مع تجميل رأس العضو الذكرى

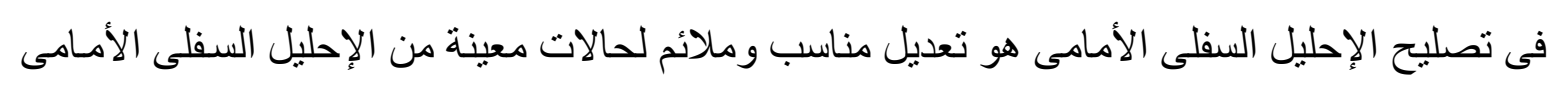

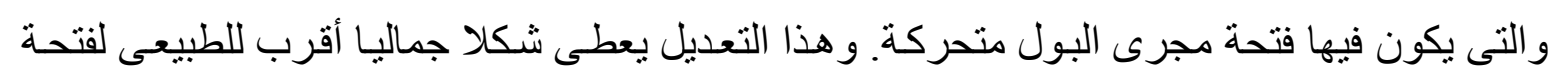
مجرى البول المشقوقة طوليا من طرف الحشفة مجنة 